\title{
Stylized features of the investment-growth connection in Latin America, 1980-2012
}

\author{
Sandra Manuelito and Luis Felipe Jiménez
}

ABSTRACT

\begin{abstract}
Estimates of investment and its components in Latin America over the past 30 years are used to review stylized facts relating to investment and explore factors that explain its connection with economic growth. In particular, the low level of investment, the reduction in public spending in the 1980s and its partial recovery along with private investment between 2003 and 2010 are explored. It is found that the increase in national income -on the back of rising terms of trade- made it possible to increase national saving and its contribution to financing investment between 2004 and 2008. The analysis of causality between the investment ratio and growth in gross domestic product (GDP) suggest that - for a considerable number of Latin American countries - changes in the growth rate have preceded changes in the investment ration in the period under study.
\end{abstract}

KEYWORDS

JEL CLASSIFICATION

AUTHORS
Investments, public investment, capital, capital formation, national income, savings, economic growth, Latin America

E01, E21, E22

Sandra Manuelito is an Economic Affairs Officer in the Economic Development Division of the Economic Commission for Latin America and the Caribbean (ECLAC). sandra.manuelito@cepal.org

Luis Felipe Jiménez is an expert with the Economic Development Division of the Economic Commission for Latin America and the Caribbean (ECLAC). 1fjimenez1953@gmail.com 


\section{I}

\section{Introduction}

One of the difficulties involved in analysing growth and macroeconomic performance in Latin America has been the lack of statistical information on the evolution of certain variables compiled in the countries' national accounts. In particular, more disaggregated information is needed on levels of investment by institutional agent and destination sector, and on investment financing, i.e. on saving and its components. This article aims to fill some of those statistical gaps and describe the main stylized features of investment and saving in the period 1980-2012. In addition, the statistical information compiled is used as the basis for an empirical exploration of the nexus between investment and growth.

On the basis of official statistics from the national accounts of the countries of the region, estimates were prepared for gross fixed capital formation (GFCF) and its components, both by institutional sector (public and private investment) and by type of investment (in construction and in machinery and equipment). To this end, annual national accounts data reported by statistical institutes or central banks in the Latin American countries were compiled and systematized along with statistical datasets prepared and published by the Economic Commission for Latin America and the Caribbean (ECLAC), as well as data taken from different sources (national statistical yearbooks, ministerial reports, national statistical bulletins) and in different formats (electronic files and printed documents), which had not been previously grouped or systematized. Where statistical information

The authors would like to express their thanks to Manuel Marfán, Juan Alberto Fuentes, Luis Felipe Céspedes, Osvaldo Kacef and Luis Eduardo Escobar for their comments on preliminary versions of this article, to Michael Seitz for his involvement in processing the statistical data, and to two anonymous reviewers for their comments. was not available, the systematization was performed for those years for which it was possible to interpolate either growth rates or ratios. When this was not possible, no data were obtained. In all the other cases, the methodology ensures the consistency and coherence of the investment data series estimated using official information from the national accounts published by the countries.

Estimates were also performed for total savings series, both external and national, the latter broken down into public and private saving. The limited availability of institutional accounts prepared by the countries precluded advancing towards a regional estimate of non-financial private sector saving and household saving.

The statistical series corresponding to these estimates are available for consultation. ${ }^{1}$ They have a broad range of possible theoretical and applied uses, and are highly relevant to study of investment trends in the period 1980-2010 in Latin America.

The article is structured as follows. Following this introduction, section II discusses the main stylized facts relating to investment, its evolution and the factors underlying its increase in the period 1980-2012. Section III presents an empirical approach to the relation between growth and investment in Latin America. Lastly, section IV offers a summary and sets forth the more significant conclusions.

\footnotetext{
${ }^{1}$ The statistical series used in this study are an updated version of the series published in Manuelito and Jiménez (2013), and are available in electronic format upon request from the authors. Although every effort was made to ensure that these statistical series are compatible with the official statistics published by the countries, as in other ECLAC publications, these estimates do not correspond to official data from the countries, so citation of the source of information should refer to the present article.
} 


\section{II}

\section{Main stylized facts in relation to investment in 1980-2012}

\section{Evolution of investment over the period}

Compared to emerging countries which have managed to sustain high GDP growth rates, the investment rate in the Latin American countries is generally low. Taking 1980 as a starting point, GFCF fell steadily as a percentage of GDP in the first half of the 1980s and remained below $20 \%$ until 2007, bottoming out in 2003 at $16.7 \%$. From that point on, the investment rate rose steadily and reached $22.9 \%$ in 2012, which nevertheless fell short of the figures for 1980 and 1981 (see figure 1). ${ }^{2}$

${ }^{2}$ Following investment statistics compilation practices, investment and its components are presented using calculations at constant prices. By contrast, statistics relating to investment financing -i.e. total saving - are presented at current prices. This is because, first, we attempt to be consistent with the statistics published by the countries in the statistical series on which the analysis in this article is based. And, second, methodological differences arise when attempting to define a deflator for savings, on which there is no technical consensus regarding either the most suitable deflator or its economic interpretation. This article takes as a reference the series in local currency at constant prices published by the countries included in the study, maintaining the respective national accounts basis, since the aim here is to compile relatively long series of investment rates as percentages of GDP.
This performance contrasts with that of the Asian emerging economies, which have recorded high growth rates over recent decades. Figure 2 compares the investment rate in these economies and in Latin America. China and India stand out among the Asian economies, with high investment rates of around $45 \%$ and $35 \%$ of GDP, respectively, followed by the Republic of Korea and Thailand, with levels of almost $25 \%$ of GDP. Except for the past few years, Latin America's investment rate has been consistently lower than in these countries.

Calculating the investment ratio on the basis of absolute values obtained by retropolation would have generated different investment ratios from those the countries publish on the basis of their official figures. In addition, on this occasion statistical information was too limited to calculate or estimate gross fixed capital formation series at current prices. Few countries in the region compile this national accounts aggregate, and the data available become increasingly scant as longer time series are attempted. In addition, there are methodological elements, such as prices implicit in the estimation of gross capital formation at current prices which, for the period under study (1980-2012), create difficulties for economic analysis, owing, in particular, to episodes of high inflation in the region in the late 1980s and early 1990s.

FIGURE 1

Latin America: gross fixed capital formation as a percentage of GDP, 1980-2012 (Dollars at constant 2005 prices)

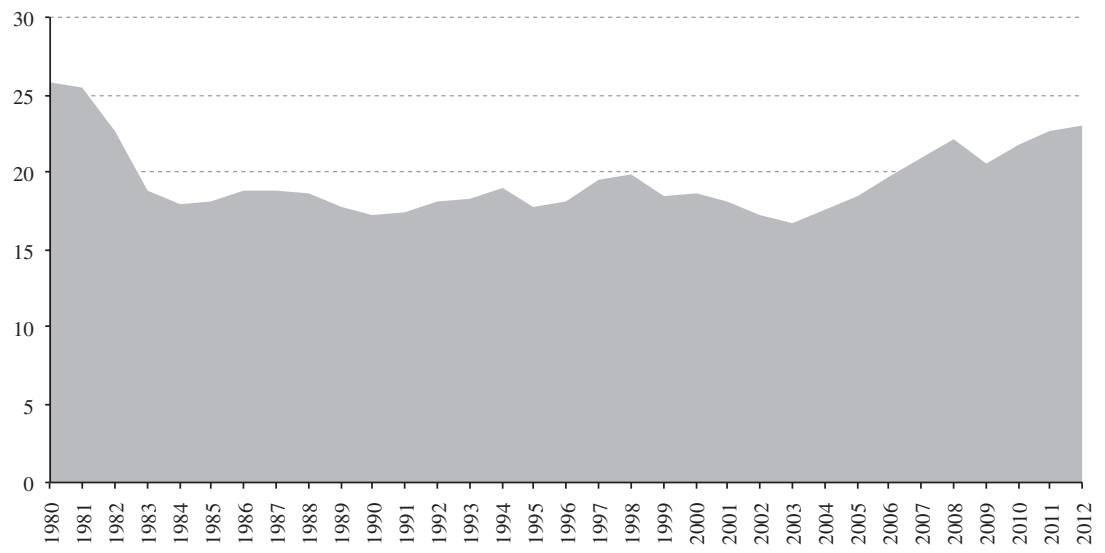

Source: prepared by the authors on the basis of Economic Commission for Latin America and the Caribbean (ECLAC), "América Latina y el Caribe: Series históricas de estadísticas económicas 1950-2008", Cuadernos Estadísticos de la CEPAL, No. 37 (LC/G.2415-P), Santiago, Chile, 2009.

GDP: gross domestic product. 
FIGURE 2

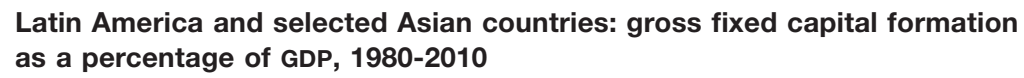

(Local currency at constant prices and dollars at constant 2005 prices)

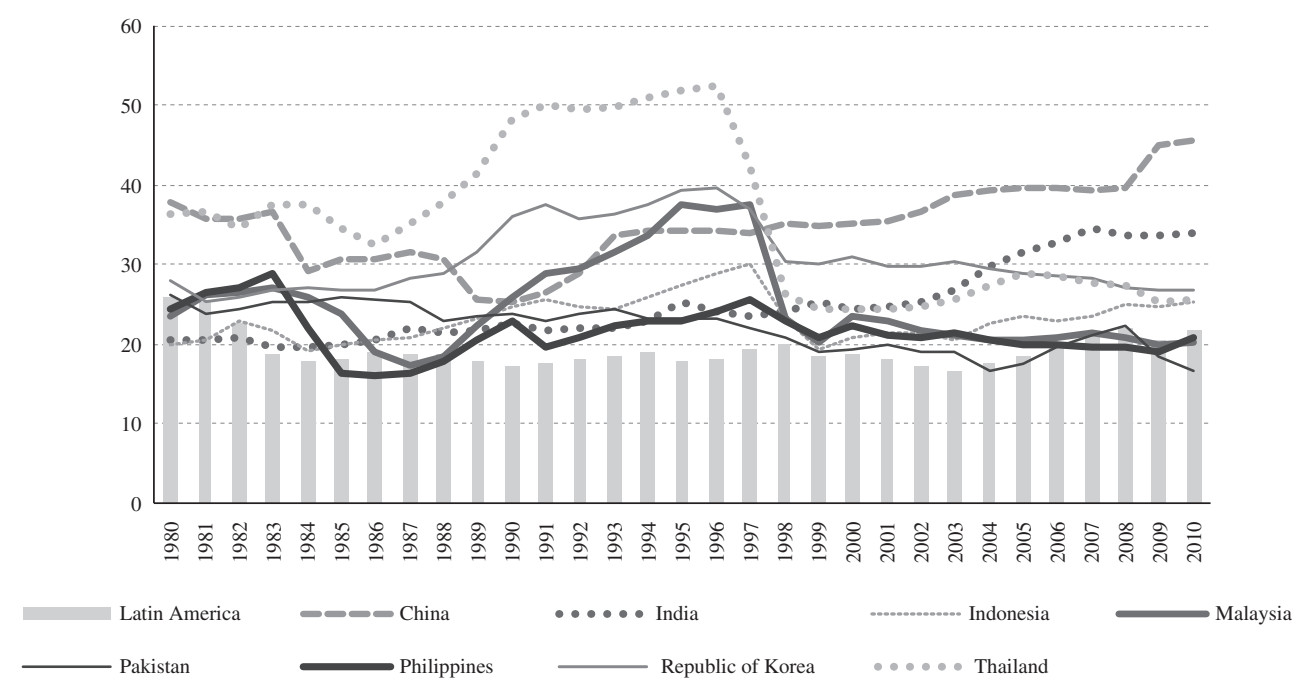

Source: prepared by the authors on the basis of Economic Commission for Latin America and the Caribbean (ECLAC), "América Latina y el Caribe: Series históricas de estadísticas económicas 1950-2008”, Cuadernos Estadísticos de la CEPAL, No. 37 (LC/G.2415-P), Santiago, Chile, 2009, and United Nations, data from UNdata.

GDP: gross domestic product.

Tables 1, 2 and 3 show the average investment rate 3 for 19 Latin American countries for which statistics are available for 1980-2010, broken down by institutional sector (public and private investment), and by type of investment (investment in construction and in machinery and equipment). The data are presented by subperiods defined according to the features of regional economic activity. The first subperiod runs from 1980 to 1989 and corresponds to the years of Latin America's external debt crisis. The second is 1990-1998, years of widespread and fairly steady economic growth, except in Argentina and Mexico, which both suffered the effects of Mexico's balance-of-payments crisis in 1994-1995.

The third subperiod is 1999-2002, when many of the region's economies experienced slow growth owing to fallout from the Asian crisis, financial shocks in some Latin American countries and economic slowdown in the United States in 2000-2001. Lastly, the fourth subperiod runs from 2003 to 2010, the recent growth years in the Latin American economies. Although this growth was interrupted in 2009 by the impacts of the global financial

\footnotetext{
${ }^{3}$ Measured as gross fixed capital formation as a percentage of GDP in local currency at constant prices.
}

crisis, the region's average growth rates in 2010 were similar to those for the period 2003-2008.

Analysis of the results shown in tables 1 and 2 leads to three stylized facts. First, in 8 of the 19 countries included (Argentina, Brazil, Cuba, El Salvador, Guatemala, Paraguay, Plurinational State of Bolivia and Uruguay), GFCF remained below $20 \%$ for lengthy periods. Second, public investment as a percentage of GDP was lower in the subperiod 1990-1998 than in the 1980s in 15 of the 19 countries, and in some of them into the subperiod 1999-2002 as well. In 2003, public investment began to rise in relation to GDP in 8 of the 19 countries, but in 13 remained below the 1980s figure. ${ }^{4}$ The third stylized fact is that, by contrast with the performance of public investment, in the 1990s private investment rose in 14 of the 19 countries. Private investment has performed unevenly since 2003 ; in 8 countries it was down on the records for 1999-2002, but in 7 it reached the highest levels for the entire period examined.

Analysis of table 3 shows that, although the rate of investment in construction was uneven from one

\footnotetext{
${ }^{4}$ Public investment refers to investment by the central government, i.e. excluding investment by State-owned firms, which are included under private investment.
} 
TABLE 1

Latin America: gross fixed capital formation as a percentage of GDP, 1980-2010a

(Local currency at constant prices)

\begin{tabular}{|c|c|c|c|c|}
\hline Country & 1980-1989 & $1990-1998$ & 1999-2002 & 2003-2010 \\
\hline Argentina & 19.3 & 18.4 & 16.0 & 20.3 \\
\hline Bolivia (Plurinational State of) & 12.1 & 16.0 & 16.6 & 14.8 \\
\hline Brazil & 18.5 & 18.1 & 15.9 & 17.3 \\
\hline Chile & 17.6 & 26.4 & 23.0 & 24.7 \\
\hline Colombia & 16.6 & 20.0 & 13.7 & 21.5 \\
\hline Costa Rica & 19.7 & 20.9 & 20.9 & 21.8 \\
\hline Cuba & 25.5 & 14.8 & 11.8 & 11.5 \\
\hline Ecuador & 18.4 & 24.9 & 22.7 & 27.0 \\
\hline El Salvador & 12.5 & 17.8 & 19.2 & 18.1 \\
\hline Guatemala & 9.7 & 10.4 & 15.6 & 17.3 \\
\hline Honduras & 16.7 & 21.8 & 24.9 & 24.8 \\
\hline Mexico & 18.9 & 17.9 & 20.0 & 21.1 \\
\hline Nicaragua & 18.4 & 18.6 & 25.3 & 21.7 \\
\hline Panama & 18.2 & 20.9 & 18.5 & 20.9 \\
\hline Paraguay & 21.9 & 22.9 & 16.6 & 17.9 \\
\hline Dominican Republic & 18.8 & 19.0 & 23.1 & 19.1 \\
\hline Uruguay & 12.7 & 14.5 & 13.0 & 16.8 \\
\hline Venezuela (Bolivarian Republic of) & 20.9 & 17.7 & 24.4 & 27.3 \\
\hline Latin Americab & 17.7 & 19.0 & 19.0 & 20.4 \\
\hline
\end{tabular}

Source: Economic Commission for Latin America and the Caribbean (ECLAC), Statistical Yearbook for Latin America and the Caribbean, various years.

a In tables 1-7 simple averages are used to calculate the aggregate regional investment rate. Giving all the countries equal weight in the regional aggregate enables comparison between them, regardless of the size of their economy, and facilitates comparison of a given country's experience vis-à-vis a typical case in the region. If the weighted average were used, the typical regional case would be represented by the three largest economies. In fact, both practices are used in ECLAC documents, depending on whether the focus of the analysis is the regionwide performance (in which case weighted averages are used) or policy matters (in which case simple averages of the figures for the countries are more suitable).

b Simple average for the countries included.

GDP: gross domestic product.

TABLE 2

Latin America: public and private gross fixed capital formation as a percentage of GDP, 1980-2010

(Local currency at constant prices)

\begin{tabular}{|c|c|c|c|c|c|c|c|c|}
\hline \multirow{2}{*}{ Country } & \multicolumn{4}{|c|}{ Public investment } & \multicolumn{4}{|c|}{ Private investment } \\
\hline & 1980-1989 & 1990-1998 & 1999-2002 & $2003-2010$ & $1980-1989$ & $1990-1998$ & 1999-2002 & $2003-2010$ \\
\hline Argentina & 1.7 & 1.5 & 1.2 & 2.4 & 17.6 & 16.9 & 14.8 & 17.9 \\
\hline Bolivia (Plurinational State of) & 8.0 & 7.4 & 5.3 & 7.4 & 4.1 & 8.6 & 11.4 & 7.4 \\
\hline Brazil & 2.2 & 2.7 & 1.7 & 1.8 & 16.4 & 15.4 & 14.2 & 15.5 \\
\hline Chile & 2.4 & 2.2 & 2.5 & 2.4 & 15.2 & 24.2 & 20.5 & 22.4 \\
\hline Colombia & 7.6 & 4.7 & 3.2 & 3.7 & 9.0 & 15.2 & 10.5 & 17.8 \\
\hline Costa Rica & 6.1 & 4.6 & 2.9 & 1.9 & 13.6 & 16.3 & 18.0 & 19.9 \\
\hline Ecuador & 5.7 & 4.2 & 5.1 & 7.3 & 12.6 & 20.7 & 17.6 & 19.7 \\
\hline El Salvador & 2.0 & 3.4 & 3.0 & 2.3 & 10.4 & 14.4 & 16.3 & 15.9 \\
\hline Guatemala & 3.5 & 3.0 & 3.4 & 2.6 & 6.1 & 7.4 & 12.2 & 14.7 \\
\hline Honduras & 7.7 & 7.7 & 5.1 & 3.9 & 9.0 & 14.1 & 19.8 & 20.8 \\
\hline Mexico & 7.1 & 3.7 & 3.3 & 4.8 & 11.8 & 14.2 & 16.7 & 16.4 \\
\hline Nicaragua & 10.8 & 7.2 & 6.1 & 4.0 & 7.6 & 11.4 & 19.2 & 17.7 \\
\hline Panama & 5.6 & 3.7 & 5.0 & 5.8 & 12.6 & 17.3 & 13.5 & 15.1 \\
\hline Paraguay & 5.2 & 3.8 & 2.7 & 3.0 & 16.7 & 19.2 & 13.9 & 13.1 \\
\hline Dominican Republic & 4.1 & 3.3 & 2.3 & 1.5 & 14.7 & 15.6 & 20.7 & 17.7 \\
\hline Uruguay & 4.6 & 3.6 & 3.3 & 4.0 & 8.1 & 10.9 & 9.8 & 12.7 \\
\hline Venezuela (Bolivarian Republic of) & 11.4 & 9.6 & 9.0 & 15.7 & 9.5 & 8.1 & 15.4 & 12.0 \\
\hline Latin America ${ }^{a}$ & 5.6 & 4.6 & 4.0 & 4.6 & 11.7 & 14.3 & 15.0 & 15.7 \\
\hline
\end{tabular}

Source: prepared by the authors, on the basis of official figures of the countries and S. Manuelito and L.F. Jiménez, "La inversión y el ahorro en América Latina: Nuevos rasgos estilizados, requerimientos para el crecimiento y elementos para una estrategia para fortalecer su financiamiento", Macroeconomía del Desarrollo series, No. 129 (LC/L.3603), Santiago, Chile, Economic Commission for Latin America and the Caribbean (ECLAC), 2013.

a Simple average for the countries included.

GDP: gross domestic product. 
Latin America: public and private gross fixed capital formation in construction and in machinery and equipment as a percentage of GDP, 1980-2010

(Local currency at constant prices)

\begin{tabular}{|c|c|c|c|c|c|c|c|c|}
\hline \multirow{2}{*}{ Country } & \multicolumn{4}{|c|}{ Investment in construction } & \multicolumn{4}{|c|}{ Investment in machinery and equipment } \\
\hline & $1980-1989$ & $1990-1998$ & 1999-2002 & 2003-2010 & 1980-1989 & 1990-1998 & $1999-2002$ & 2003-2010 \\
\hline Argentina & 12.5 & 11.1 & 10.0 & 12.2 & 6.7 & 7.4 & 6.0 & 8.1 \\
\hline Bolivia (Plurinational State of) & 6.2 & 8.1 & 8.6 & 8.0 & 5.9 & 7.9 & 8.1 & 6.8 \\
\hline Brazil & 12.6 & 12.7 & 10.6 & 10.2 & 5.9 & 5.5 & 5.3 & 7.1 \\
\hline Chile & 9.9 & 13.2 & 14.0 & 13.4 & 7.7 & 13.2 & 9.1 & 11.3 \\
\hline Colombia & 8.7 & 11.5 & 8.2 & 12.3 & 7.9 & 8.4 & 5.4 & 8.3 \\
\hline Costa Rica & 9.3 & 8.7 & 8.8 & 10.1 & 10.4 & 12.2 & 12.1 & 11.8 \\
\hline Cuba & $\ldots$ & 10.9 & 9.6 & 8.4 & $\ldots$ & 3.9 & 2.3 & 3.1 \\
\hline Ecuador & 9.8 & 12.3 & 13.4 & 15.5 & 8.6 & 12.7 & 9.2 & 11.6 \\
\hline El Salvador & 6.3 & 8.5 & 8.5 & 7.3 & 6.2 & 9.3 & 10.7 & 10.9 \\
\hline Guatemala & 4.7 & 4.5 & 6.5 & 7.3 & 5.0 & 5.9 & 9.1 & 10.0 \\
\hline Honduras & 10.6 & 11.5 & 10.1 & 7.4 & 6.1 & 10.4 & 14.8 & 17.3 \\
\hline Mexico & 11.5 & 9.5 & 9.1 & 13.1 & 7.4 & 8.4 & 10.8 & 7.9 \\
\hline Nicaragua & 5.8 & 8.3 & 11.3 & 8.9 & 12.6 & 10.3 & 14.0 & 12.8 \\
\hline Panama & 12.0 & 10.3 & 8.9 & 10.8 & 6.1 & 10.6 & 9.6 & 10.1 \\
\hline Paraguay & 13.5 & 11.3 & 9.5 & 9.1 & 8.4 & 11.6 & 7.2 & 8.8 \\
\hline Peru & 12.7 & 12.0 & 11.0 & 12.2 & 7.8 & 8.5 & 7.9 & 10.4 \\
\hline Dominican Republic & 14.2 & 14.0 & 17.1 & 14.9 & 4.6 & 4.9 & 6.0 & 4.3 \\
\hline Uruguay & 8.4 & 7.8 & 7.5 & 8.9 & 4.3 & 6.7 & 5.5 & 7.5 \\
\hline Venezuela (Bolivarian Republic of) & 11.5 & 10.8 & 13.0 & 12.3 & 9.5 & 6.7 & 10.3 & 13.8 \\
\hline Latin America ${ }^{a}$ & 10.0 & 10.4 & 10.3 & 10.6 & 7.3 & 8.7 & 8.6 & 9.6 \\
\hline
\end{tabular}

Source: prepared by the authors, on the basis of official figures of the countries and S. Manuelito and L.F. Jiménez, "La inversión y el ahorro en América Latina: Nuevos rasgos estilizados, requerimientos para el crecimiento y elementos para una estrategia para fortalecer su financiamiento", Macroeconomía del Desarrollo series, No. 129 (LC/L.3603), Santiago, Chile, Economic Commission for Latin America and the Caribbean (ECLAC), 2013.

a Simple average for the countries included. GDP: gross domestic product.

country to another throughout the period 1980-2010, in several it behaved similarly to public investment. On average, however, investment in construction held relatively steady at around 10\% of GDP between 1980 and 2010. Investment in machinery and equipment behaved similarly to private investment, rising over the preceding subperiod in 1990-1998 (in 15 of the 19 countries) and 2003-2010 (in 14 of 19 countries). The regional average for that type of investment was considerably higher, in the subperiod 2003-2010 than in the 1980s (9.6\% of GDP compared with $7.3 \%$ of GDP).

\section{Factors influencing the rise in investment in 1990-1998 and 2003-2010}

Although the purpose of this article is not to build an econometric model to establish the contribution or impact of different factors to the variation of the investment rate in the period under consideration, the ongoing analyses conducted by ECLAC reveal a number of elements that help to explain the phenomenon..$^{5}$ Thus, the greater availability of foreign-exchange financing - and the consequent easing of the external constraint on growthwas one of the factors contributing to a modest rise in the investment rate in 1990-1998 and 2003-2010. This was also a factor in the rise in investment in machinery and equipment.

Most of the Latin American economies became increasingly open in the period 1990-1998 (some had already embarked upon this strategy in the second half of the 1980s). This opened up certain sectors to foreign direct investment (FDI) and led to the privatization of utilities and banking services, which boosted investment flows into the region. Foreign trade was also opened up and trade integration processes gained ground, including the

\footnotetext{
5 This discussion is supported by the analysis and evidence presented in the editions of the Economic Survey for Latin America and the Caribbean published each year by ECLAC.
} 
North American Free Trade Area (NAFTA), the Southern Common Market (MERCosUR), and the establishment of maquila industries in Central America. These processes all attracted increasing amounts of investment and boosted goods exports, mainly through the expansion of export volumes. ${ }^{6}$

Together with the increase in exports, in 1990-1998 international prices came down for manufactures but rose for some raw materials, at least until the Asian crisis of $1997 .{ }^{7}$ As a result, the region saw the purchasing power of its exports ${ }^{8}$ rise, especially in Mexico, thanks to NAFTA, and in the Central American countries, owing to maquila-related investments. ${ }^{9}$ Despite the larger inflows of foreign exchange, however, the structure of the region's investment financing remained unchanged. As will be discussed later, in 1990-1998 investment financing became even more reliant on external saving, partly as a result of more ready access, to the detriment of national-savings-based financing (see table 7).

There was a second factor facilitating the rise in investment, and especially investment in machinery and equipment. The flow of foreign exchange into the economies of the region, as a result of increased exports and the incipient development of a financial market in several of the countries, contributed to exchange-rate appreciations which cheapened local-currency costs of imported goods. This is important, given the large share of imported capital goods in machinery and equipment investment in the countries of the region. In four countries (Argentina, Brazil, Ecuador and Mexico), real exchange-rate appreciation was sharper still, owing

\footnotetext{
${ }^{6}$ The maquila industry also brought a considerable increase in goods imports, so that the rise in goods exports had a limited impact in terms of improving the trade balances of the Latin American countries.

${ }^{7}$ In particular, international prices for beef, coffee, soybeans and wheat. Prices for metals and minerals were more volatile, although form 1993 to 1995 international prices for aluminium, copper and nickel rose by over $50 \%$ in cumulative terms. Later, when the Asian crisis broke out, raw materials prices fell across the board and remained low until 2003.

8 The purchasing power of exports may be defined as the value of goods exports measured in terms of their purchasing power of goods imports. In other words, it corresponds to the volume of exports multiplied by the terms of trade, as given in the following expression:

$P C E=Q x *\left(\frac{P x}{P m}\right)$

where

$Q x=$ the volume index of goods exports,

$P x=$ the price index of goods exports, and

$P m=$ the price index of goods imports.

${ }^{9}$ It must be recalled, however, that goods exports have quite a large imported component in both cases, so that the greater exports produced only a very limited rise in national income.
}

to schemes to counter inflation that used the exchange rate as a nominal anchor.

All this combined with a downtrend in international prices for capital goods, ${ }^{10}$ which had begun in the 1980s and sharpened in the 1990s. International prices for capital goods fell by $23 \%$ between 1980 and 1990 and by a further $42 \%$ between 1990 and 2000, based on the unit value index of capital goods imports from the United States, prepared by the Bureau of Economic Analysis (see figure 3). ${ }^{11}$

The cycle of investment expansion was broken in 1997-1998 by the onset of the Asian crisis. Between 1990 and 1998, in several countries burgeoning domestic demand had generated current-account disequilibria which were unsustainable when the external financing constraint hit. As a result, several countries were forced to adjust domestic demand, which accounts for the fall in investment rates, especially in machinery and equipment, between 1999 and 2002.

The second subperiod in which investment rates rose, 2003 to 2010, showed a significant shift in relation to the trends for 1998-2002. Disposable gross national income began to climb strongly in several countries starting in the second half of 2003 and swelled national saving, public and private alike, owing chiefly to large terms-of-trade gains as a result of the sudden rise in international commodity prices (see table 4).

Analysis of private and public national saving presents certain difficulties of comparison between the countries, because some calculate net saving (i.e. net of fixed capital consumption), while others estimate gross saving. The comparison of the two definitions is inexact, yet over time sheds light on macroeconomic aspects of investment financing (see tables 5 and 6).

Although data availability is uneven over time, in both subperiods in which public saving rose, it rose both with respect to the preceding subperiod and by comparison with the period 1980-1989. Public saving rose more during the subperiod 2003-2010, especially in the countries in which natural resources account for a large percentage of fiscal income ${ }^{12}$ - Argentina, Bolivarian Republic of Venezuela, Chile, Ecuador, Peru and the Plurinational State of Bolivia - with the exception of Mexico.

\footnotetext{
${ }^{10}$ Refers to the index for capital goods excluding automobiles.

11 This index is used here as a reference only for international capital goods prices that are relevant for the region, because the structure of capital goods imports in the United States does not necessarily coincide with that of the Latin American countries.

12 See ECLAC (2011, table I.2) which shows the increasing weight of income from primary goods in fiscal revenues in several countries.
} 
FIGURE 3

Index of capital goods import prices, excluding automobiles, 1980-2011

(Index: 2005=100)

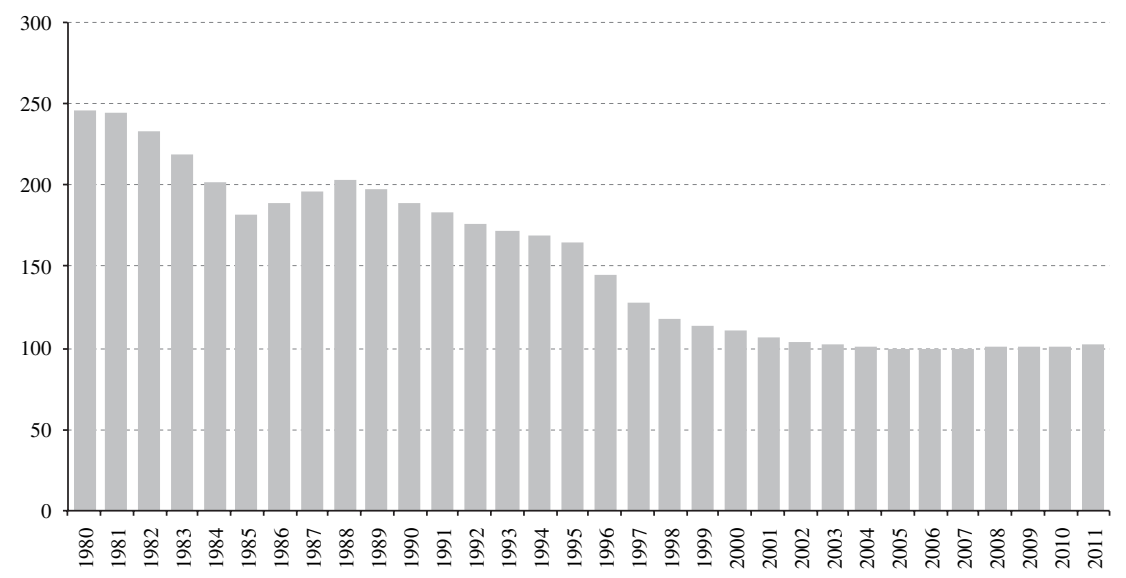

Source: prepared by the authors, on the basis of figures from the Bureau of Economic Analysis of the United States Department of Commerce.

TABLE 4

Latin America: national saving as a percentage of GDP, 1980-2010

(Local currency at constant prices)

\begin{tabular}{lrrrr}
\hline Country & $1980-1989$ & $1990-1998$ & $1999-2002$ & $2003-2010$ \\
\hline Argentina & 17.9 & 15.8 & 15.4 & 24.1 \\
Bolivia (Plurinational State of) & 16.4 & 9.8 & 10.7 & 22.2 \\
Brazil & 20.1 & 17.2 & 13.6 & 17.7 \\
Chile & 11.8 & 22.3 & 20.7 & 22.9 \\
Colombia & 18.5 & 20.6 & 15.2 & 19.6 \\
Costa Rica & 16.1 & 14.5 & 13.3 & 16.8 \\
Cuba & $\ldots$ & $\ldots$ & $\ldots$ & 10.9 \\
Ecuador & $\ldots$ & 17.3 & 22.2 & 22.1 \\
El Salvador & $\ldots .9$ & 14.9 & 14.3 & 11.6 \\
Guatemala & 9.5 & 11.0 & 12.5 & 14.1 \\
Honduras & 4.5 & 18.3 & 17.2 & 20.0 \\
Mexico & 21.7 & 19.1 & 19.4 & 24.0 \\
Nicaragua & 3.6 & 2.0 & 10.3 & 13.1 \\
Panama & 24.7 & 24.7 & 18.4 & 20.0 \\
Paraguay & 19.8 & 21.0 & 17.5 & 17.3 \\
Peru & 21.3 & 15.5 & 17.3 & 21.4 \\
Dominican Republic & 15.7 & 16.5 & 18.9 & 15.0 \\
Uruguay & 11.7 & 13.8 & 11.9 & 16.5 \\
Venezuela (Bolivarian Republic of) & 22.7 & 23.1 & 30.6 & 34.3 \\
Latin America & 16.0 & 16.5 & 16.6 & 19.2 \\
\hline
\end{tabular}

Source: prepared by the authors, on the basis of official figures from the countries and S. Manuelito and L.F. Jiménez, "La inversión y el ahorro en América Latina: Nuevos rasgos estilizados, requerimientos para el crecimiento y elementos para una estrategia para fortalecer su financiamiento", Macroeconomía del Desarrollo series, No. 129 (LC/L.3603), Santiago, Chile, Economic Commission for Latin America and the Caribbean (ECLAC), 2013.

a Simple average for the countries included.

GDP: gross domestic product. 
TABLE 5

Latin America: public saving as a percentage of GDP, 1980-2010

(Local currency at constant prices)

\begin{tabular}{|c|c|c|c|c|}
\hline Country & $1980-1989$ & $1990-1998$ & $1999-2002$ & $2003-2010$ \\
\hline \multicolumn{5}{|l|}{ I. Countries which report gross public saving } \\
\hline $\begin{array}{l}\text { Argentina } \\
\text { Bolivia (Plurinational State of) } \\
\text { Brazil } \\
\text { Colombia } \\
\text { Cuba } \\
\text { El Salvador } \\
\text { Guatemala } \\
\text { Nicaragua } \\
\text { Dominican Republic } \\
\text { Uruguay }_{\text {Average }^{\mathrm{a}}}\end{array}$ & $\begin{array}{r}\ldots \\
-3.8 \\
\ldots \\
2.5 \\
\ldots \\
\ldots \\
\ldots \\
\ldots \\
\ldots \\
-0.2 \\
-0.5\end{array}$ & $\begin{array}{r}-0.2 \\
2.6 \\
1.7 \\
3.6 \\
\ldots \\
1.3 \\
1.8 \\
2.3 \\
3.7 \\
3.3 \\
2.2\end{array}$ & $\begin{array}{r}-1.5 \\
-1.7 \\
1.3 \\
-1.6 \\
\ldots \\
0.2 \\
2.3 \\
0.3 \\
3.4 \\
-2.3 \\
0.0\end{array}$ & $\begin{array}{r}2.4 \\
4.7 \\
0.5 \\
1.0 \\
2.2 \\
0.0 \\
2.4 \\
1.1 \\
2.1 \\
-0.5 \\
1.6\end{array}$ \\
\hline \multicolumn{5}{|l|}{ II. Countries which report net public saving } \\
\hline $\begin{array}{l}\text { Chile } \\
\text { Costa Rica } \\
\text { Ecuador } \\
\text { Honduras } \\
\text { Mexico } \\
\text { Panama } \\
\text { Paraguay } \\
\text { Peru } \\
\text { Venezuela (Bolivarian Republic of) } \\
\text { Average }^{\text {a }}\end{array}$ & $\begin{array}{r}3.2 \\
\ldots \\
\ldots \\
\ldots \\
-2.8 \\
1.2 \\
-1.7 \\
\ldots \\
0.0\end{array}$ & $\begin{array}{l}4.4 \\
2.4 \\
4.9 \\
1.0 \\
4.1 \\
3.0 \\
2.6 \\
0.6 \\
9.2 \\
3.6\end{array}$ & $\begin{array}{r}0.8 \\
2.6 \\
3.5 \\
2.6 \\
1.6 \\
0.7 \\
1.4 \\
-0.3 \\
1.4 \\
1.6\end{array}$ & $\begin{array}{l}5.5 \\
3.7 \\
7.9 \\
0.0 \\
2.0 \\
1.2 \\
5.2 \\
2.5 \\
4.9 \\
3.7\end{array}$ \\
\hline
\end{tabular}

Source: prepared by the authors, on the basis of official figures from the countries and S. Manuelito and L.F. Jiménez, "La inversión y el ahorro en América Latina: Nuevos rasgos estilizados, requerimientos para el crecimiento y elementos para una estrategia para fortalecer su financiamiento", Macroeconomía del Desarrollo series, No. 129 (LC/L.3603), Santiago, Chile, Economic Commission for Latin America and the Caribbean (ECLAC), 2013.

a Simple average for the countries included.

GDP: gross domestic product.

TABLE 6

Latin America: private saving as a percentage of GDP, 1980-2010

(Local currency at constant prices)

\begin{tabular}{|c|c|c|c|c|}
\hline Country & 1980-1989 & $1990-1998$ & 1999-2002 & $2003-2010$ \\
\hline \multicolumn{5}{|l|}{ I. Countries which report gross public saving } \\
\hline $\begin{array}{l}\text { Argentina } \\
\text { Bolivia (Plurinational State of) } \\
\text { Brazil } \\
\text { Colombia } \\
\text { Cuba } \\
\text { El Salvador } \\
\text { Guatemala } \\
\text { Nicaragua } \\
\text { Dominican Republic } \\
\text { Uruguay }_{\text {Average }^{\mathrm{a}}}\end{array}$ & $\begin{array}{r}20.2 \\
\ldots \\
16.1 \\
\ldots \\
\ldots \\
\ldots \\
\ldots \\
\ldots \\
11.9 \\
16.1\end{array}$ & $\begin{array}{r}16.8 \\
7.2 \\
11.6 \\
17.0 \\
\ldots \\
13.6 \\
9.2 \\
0.8 \\
12.7 \\
10.5 \\
11.1\end{array}$ & $\begin{array}{r}16.9 \\
12.5 \\
12.3 \\
16.9 \\
\ldots \\
14.1 \\
10.2 \\
10.0 \\
15.6 \\
14.1 \\
13.6\end{array}$ & $\begin{array}{r}21.6 \\
17.9 \\
17.2 \\
18.8 \\
\ldots \\
11.7 \\
11.8 \\
12.0 \\
12.9 \\
15.6 \\
15.5\end{array}$ \\
\hline \multicolumn{5}{|l|}{ II. Countries which report net public saving } \\
\hline $\begin{array}{l}\text { Chile } \\
\text { Costa Rica } \\
\text { Ecuador } \\
\text { Honduras } \\
\text { Mexico } \\
\text { Panama } \\
\text { Paraguay } \\
\text { Peru } \\
\text { Venezuela (Bolivarian Republic of) } \\
\text { Average }^{\mathrm{a}}\end{array}$ & $\begin{array}{r}9.6 \\
-3.1 \\
\ldots \\
. . \\
20.6 \\
8.2 \\
17.2 \\
. .\end{array}$ & $\begin{array}{r}7.3 \\
6.8 \\
11.6 \\
17.3 \\
5.2 \\
14.7 \\
13.9 \\
8.4 \\
7.2 \\
10.3\end{array}$ & $\begin{array}{r}6.7 \\
4.9 \\
16.8 \\
14.7 \\
8.1 \\
9.6 \\
11.9 \\
10.4 \\
23.1 \\
11.9\end{array}$ & $\begin{array}{r}5.8 \\
7.9 \\
14.0 \\
15.5 \\
12.9 \\
11.7 \\
12.6 \\
12.1 \\
23.8 \\
12.6\end{array}$ \\
\hline
\end{tabular}

Source: prepared by the authors, on the basis of official figures from the countries and S. Manuelito and L.F. Jiménez, "La inversión y el ahorro en América Latina: Nuevos rasgos estilizados, requerimientos para el crecimiento y elementos para una estrategia para fortalecer su financiamiento", Macroeconomía del Desarrollo series, No. 129 (LC/L.3603), Santiago, Chile, Economic Commission for Latin America and the Caribbean (ECLAC), 2013.

a Simple average for the countries included. GDP: gross domestic product. 
A number of reasons underlie the performance of public saving. As noted earlier, the countries have in common the rise in national saving resulting from steadily improving terms of trade in 2003-2010. During those years, many countries also adopted fiscal policies geared towards building public finance sustainability throughout the commodity price cycle, during what was a strong price upswing. ${ }^{13}$ In the cases of Argentina and Ecuador, the rise in public saving also reflected the need to work around the consequences of restricted access to external financing.

Private saving also rose considerably as a percentage of GDP, especially in 2003-2010, the second subperiod in which the investment rate maintained an upward trend. This trend, which is evident in two thirds of the countries, reflected increased disposable gross national income (see tables 5 and 6). In some cases, the rise in private saving includes the savings of public enterprises that were not transferred to the central government. Although private saving rose in the great majority of the countries, it came down in El Salvador, Chile, the Dominican Republic and Paraguay (see table 6).

Trends in public and private savings help to explain the rise in national saving seen in 1990-1997 and, especially, in 2003-2008, when the investment rate rose steadily. In several countries, national saving also rose faster than investment, which led to a sharp fall in the share of investment financing accounted for by external saving in over half the countries examined (see table 7). In addition, in 8 of the 19 countries and in relation to GDP, public saving rose more than private saving in 2003-2008 compared to the preceding subperiod (1999-2002). ${ }^{14}$ However, these larger rises in public saving were not reflected in similar rises in public investment.

From the foregoing it may be concluded that, as well as exogenous factors (higher prices for export commodities, swelling migrant remittances, lower interest rates on external debt) that helped increase disposable gross national income in 2003-2010, policies

\footnotetext{
13 See ECLAC (2011, box I.1), which describes the gradual adoption of fiscal rules in the region starting in 2000. Box III.1 also presents the main characteristics of funds aimed at easing the impacts of fluctuations in public revenues resulting from variations in primary goods prices. 14 Where public and private saving fell, the decline in public saving was smaller than in private saving.
}

on public finance sustainability and management of international reserves also had a hand in lowering the use of external saving. As a counterpart to decreased use of external saving, external debt came down as a proportion of GDP, net international reserves swelled considerably, and public savings were built up in sovereign funds in several countries of the region. ${ }^{15}$ From this perspective, the main contrast with the economic conditions prevailing in the subperiods 1990-1998 and 2003-2010 was the larger share of national saving in financing regional investment in the latter subperiod, representing a shift towards growth sustainability and reduced vulnerability to the vicissitudes of external financial markets. When the global financial crisis of 2008-2009 broke out, the more limited use of external saving thanks to national saving in prior years enabled several countries to adopt countercyclical policies, and the region in general was able to weather the episode on a better footing, so that growth took less of a hit than in previous episodes.

With international prices for manufactures varying little, the rise in national saving boosted the purchasing power of exports again (see figure 4). The South American economies felt this effect the most, owing to their greater specialization in production and export of raw materials.

In addition, in 2003-2010 local currencies began to appreciate again in five countries (Brazil, Chile, Colombia, Mexico and Peru) which, among other things, made it cheaper to import capital goods. However, the international prices of capital goods did not play such a strong role in these years as in 1990-1998. Although capital goods prices continued to trend downwards, the variations were smaller from 2002 on, at $-6.4 \%$ between 2002 and 2011. Nevertheless, the fact remains that in 2005 capital goods prices stood at just $40 \%$ of the equivalent prices in 1980. So, amid improving terms of trade, falling prices for capital goods and exchange-rate appreciation, national saving increased in dollar terms. Together with robust economic growth in this period, this created the conditions for greater investment in machinery and equipment.

\footnotetext{
15 It will also be recalled that during this period several countries (for example, Argentina and Brazil) made early payment of their liabilities to the International Monetary Fund (IMF). Chile, too, adopted a policy of prepayment of loans from multilateral institutions from 2004 to 2006 and, like other countries, repurchased some of its external bonds.
} 
TABLE 7

Latin America: external saving as a percentage of GDP, 1980-2010

(Local currency at constant prices)

\begin{tabular}{|c|c|c|c|c|}
\hline Country & $1980-1989$ & $1990-1998$ & $1999-2002$ & $2003-2010$ \\
\hline Argentina & 2.1 & 2.7 & 0.1 & -2.7 \\
\hline Bolivia (Plurinational State of) & -1.6 & 6.9 & 4.7 & -7.3 \\
\hline Chile & 7.1 & 3.2 & 0.9 & -1.6 \\
\hline Colombia & 1.3 & 1.1 & 0.0 & 1.9 \\
\hline Costa Rica & 9.5 & 5.5 & 5.9 & 6.1 \\
\hline Ecuador & $\ldots$ & 4.4 & -0.8 & 2.1 \\
\hline El Salvador & $\ldots$ & 2.2 & 2.3 & 3.9 \\
\hline Guatemala & 3.8 & 3.4 & 6.4 & 4.1 \\
\hline Honduras & 6.8 & 5.6 & 5.7 & 6.7 \\
\hline Mexico & 0.5 & 3.8 & 2.8 & 0.7 \\
\hline Nicaragua & 17.0 & 23.2 & 20.6 & 16.0 \\
\hline Panama & -6.7 & -0.1 & 2.5 & 1.2 \\
\hline Paraguay & -5.0 & 0.8 & 1.7 & -2.5 \\
\hline Dominican Republic & 5.6 & 1.8 & 3.1 & 3.0 \\
\hline Uruguay & 2.1 & 1.3 & 1.7 & 2.5 \\
\hline Venezuela (Bolivarian Republic of) & -2.0 & -3.3 & -5.8 & -9.9 \\
\hline Latin America ${ }^{\mathrm{a}}$ & 2.9 & 3.9 & 3.2 & 1.3 \\
\hline
\end{tabular}

Source: prepared by the authors, on the basis of official figures from the countries and S. Manuelito and L.F. Jiménez, "La inversión y el ahorro en América Latina: Nuevos rasgos estilizados, requerimientos para el crecimiento y elementos para una estrategia para fortalecer su financiamiento", Macroeconomía del Desarrollo series, No. 129 (LC/L.3603), Santiago, Chile, Economic Commission for Latin America and the Caribbean (ECLAC), 2013.

${ }^{\text {a }}$ Simple average for the countries included. GDP: gross domestic product.

FIGURE 4

Latin America: annual average variation in purchasing power of goods exports, 1981-2010

(Percentages)

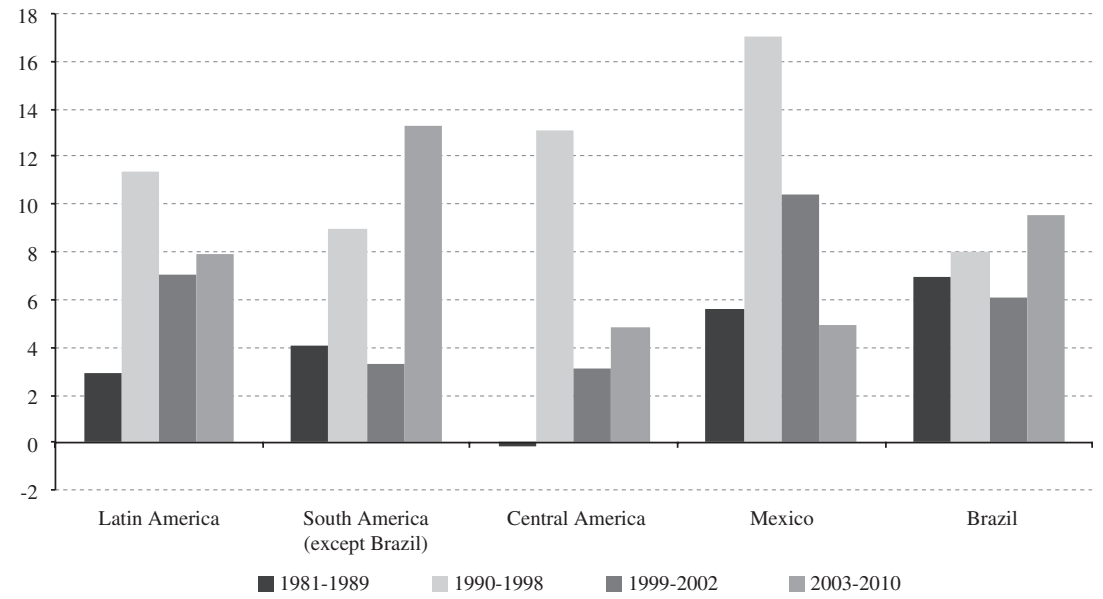

Source: prepared by the authors, on the basis of Economic Commission for Latin America and the Caribbean (ECLAC), CEPALSTAT data base. Note: the average for Latin America is the regional weighted average. Each country is given a weighting equal to its share of regional exports. The average for each of the subregions is a simple average. 


\section{III}

\section{An empirical approach to the relation between growth and investment in Latin America}

This section uses the data described and analysed above to perform an empirical examination of the relationship between growth and investment in the Latin American countries from 1980 to 2010.

From a long-term perspective, economic theory holds that achievement of a given level of economic activity depends basically on factor accumulation, technical progress and, in certain approaches, such as the one proposed by ECLAC, the characteristics of the production structure. Empirical studies show that capital accumulation is a necessary, but not a sufficient, condition for growth. This connection has been studied extensively; a good summary in this respect may be found in the work of Sala-i-Martin (1997), which uses robust estimation methods to identify at least 22 variables which are significantly correlated with economic growth. Among these, investment in machinery and equipment is prominent, contrasting with a low impact for other types of investment (for example, in construction). Real-exchange-rate distortions and the spread between the official and black market exchange rates also have a strong (negative) influence on growth (Sala-i-Martin, 1997).

Recent studies have addressed another two key aspects: the effect of public investment and FDI on economic growth. Both have been found to have a positive impact (Toulaboe, Terry and Johansen, 2009; Cullison, 1993; Bukhari, Ali and Saddaqat, 2007).

By contrast, from a short- and medium-term perspective, the level and momentum of economic activity are treated as the outcome of levels of aggregate demand, key relative prices and supply-side constraints.

This dichotomy between the timescales of theoretical analyses contrasts with the results of empirical economic growth analyses, the experience of the countries and economic policy practice, inasmuch as policies adopted for the short term weigh on long-term outcomes. The short- and medium-term emphasis on the importance of investment in fact has more to do with demand-side factors. Investment galvanizes aggregate demand (multiplier effect) and is key in determining the level of demand, especially demand with a high impact on employment. At the same time, present and future growth expectations increase the pace of investment (accelerator effect). The long-term nature of investment decisions means that growth and returns expectations are very significant factors. This is why a good present performance in a scenario of sustained growth (understood as economic performance free of heavy or persistent disequilibria) helps to generate positive expectations which favour present decisions on future investments, thereby raising the growth trajectory.

However, several empirical studies propose that short- and medium-term causality between GDP growth and the investment rate may be two-directional (Blomström, Lipsey and Zehjan, 1993; Peltonen, Sousa and Vansteenkiste, 2012; Cheung, Dooley and Sushko, 2012). Greater investment thus helps boost economic activity by impacting positively on demand, which in turn stimulates investment by reducing idle capacity and improving expectations of future returns.

In light of the points made in the preceding two paragraphs, the empirical review that follows of the investment-growth nexus is set within a short-term perspective and does not rule out mutual causality. For this reason, it uses a different methodology from empirical analyses of long-term growth. ${ }^{16}$ Focusing the analysis on the short-term link between the investment rate and growth spotlights the importance of countercyclical policies and crisis prevention in sustaining or increasing the investment rate. This, in turn, links macroeconomic policy to long-term growth, whose importance is evident in both literature and practice.

In the empirical literature, causality between growth and investment is still a matter of debate. The results obtained are inconclusive and depend to a great extent on the economy and the timescale examined and considerations such as the number of lags in the estimations, or the estimation method itself. These exercises are also complicated by the fact that the link between the two variables is examined ex post in the identity relations of the national accounts, which generates

\footnotetext{
16 The total effects of investment on growth could well take longer to materialize than the number of years analysed here. However, the quantification of those effects would require a different methodology from that employed here, as well as longer statistical series. For a recent analysis of long-term growth in Latin America and the Caribbean, see ECLAC (2014, cap. III).
} 
problems of simultaneity and makes it more difficult to demonstrate causality in one direction or the other. Bearing these limitations in mind, the existence of (Granger) causality was explored between GDP variation and the investment rate. The results are presented below, with a single lag between the variables. Exercises were performed with a higher order of lags, but a lag order of 1 produced significant results for the largest number of countries. ${ }^{17}$

Two null hypotheses were tested:

(i) Null hypothesis (1): the investment rate does not Granger-cause the rate of GDP variation. Rejection of null hypothesis (1) is interpreted as meaning that changes in the investment rate precede changes in the GDP growth rate.

(ii) Null hypothesis (2): the rate of GDP variation does not Granger-cause the investment rate. Rejection of null hypothesis (2) is interpreted as meaning that changes in the GDP growth rate precede changes in the investment rate.

For simplicity's sake, null hypothesis (1) and null hypothesis (2) will be referred to as $\mathrm{Hn}(1)$ and $\mathrm{Hn}(2)$, respectively.

Table 8 shows the results obtained from testing $\mathrm{Hn}(1)$, which examines the existence of short-term causality of the GDP growth rate by the investment rate, the public investment rate, the private investment rate, the rate of investment in construction and the rate of investment in machinery and equipment.

The results obtained from the tests performed suggest that, in general, $\mathrm{Hn}(1)$ cannot be rejected, with certain exceptions. For the 18 countries studied, in $14 \mathrm{Hn}(1)$ is not rejected at significance of at least $95 \%$, which may be interpreted as the absence of evidence of short-term causality of GDP by the investment rate. Exceptions to this result are the cases of Argentina, Brazil, Costa Rica and Panama, for which the investment does appear to have Granger-caused GDP growth in the period under study. At 90\% significance, the Bolivarian Republic of Venezuela may be added to this list.

The absence of a short-term effect on growth tends to hold in the examination of causality of GDP growth by public and private investment and by investment in

${ }^{17}$ Application of a higher lag order does not change the interpretation of the results obtained using order 1 , although the significance is lower. The qualitative results are unchanged inasmuch as no sign reversals occur, so nothing additional is learned about the nexus between the two variables. In addition, although these disaggregated series are as long as possible, they have only 30 observations, so including a larger number of lags would mean sacrificing degrees of freedom for the econometric analysis. Consequently, it was considered preferable to report simpler exercises, which can be readily replicated and contrasted in other research once the database is made available. machinery and equipment. By contrast, in the case of investment in construction, the number of countries for which $\mathrm{Hn}(1)$ is rejected rises to 8. Consequently, in these cases, investment in construction does appear to have Granger-caused GDP growth.

Table 9 shows the results of the $\operatorname{Hn}(2)$ test, which examines short-term causality by GDP of total investment, public and private investment and investment in construction and in machinery and equipment. As may be seen, the hypothesis of non-causality by GDP of total investment may be rejected for 9 of the 18 countries with at least $95 \%$ significance, and for 13 at $90 \%$ significance. This implies, with a high degree of probability, that for several countries in the region, changes in the GDP growth rate preceded and impacted positively on changes in the investment rate in the period under study. Brazil, Chile, Ecuador, Guatemala and Mexico are the exceptions to this result.

With regard to the effects of GDP growth on the components of investment, in just over half the cases, GDP growth appears to Granger-cause private investment, investment in machinery and equipment and, especially, investment in construction. By contrast, there is no evidence of GDP causality of public investment.

Comparison of the results presented in tables 8 and 9 shows that in several cases (Argentina, Costa Rica and Panama) both hypotheses are rejected, so that Granger causality between the two variables appears to be twodirectional, which bears out to some extent the studies mentioned earlier. However, formal proof of this would require a different exercise to the one performed here.

The overall results suggest that in the period 1980-2010 increases in the investment rate were related to stimuli coming from aggregate demand (growth expectations or actual increase in demand). Trends in regional aggregate demand and in the factors driving it offer certain leads to explain this performance. As for external demand, the main increases have been in global demand for commodities and energy products, which triggered a rise in investment in these sectors. ${ }^{18}$ In turn,

\footnotetext{
18 Although the great majority of the countries do not have statistics on gross fixed capital formation (GFCF) by destination sector of investment, partial information and data from other sources suggest that in raw material producers and exporters, most investment has gone to mining and energy. In the case of FDI, from 2007 to 2012 in South America (excluding Brazil), between $44 \%$ and $51 \%$ went to the natural resources sector and around $40 \%$ to services, including commerce and financial and infrastructure services. By contrast, in Mexico and Central America, between $35 \%$ and $48 \%$ went to manufacturing, and between $42 \%$ and $55 \%$ to services. In Brazil, between $38 \%$ and $43 \%$ went to manufacturing and between $34 \%$ and $48 \%$ to services (ECLAC, 2013b, figure I.11).
} 
TABLE 8

Results of the test of null hypothesis 1 on Granger causality of GDP growth by the investment rate

\begin{tabular}{|c|c|c|c|c|c|c|c|c|c|c|}
\hline & \multicolumn{2}{|c|}{$\begin{array}{c}\text { GFCF does not } \\
\text { cause GDP }\end{array}$} & \multicolumn{2}{|c|}{$\begin{array}{l}\text { INVPUB does not } \\
\text { cause GDP }\end{array}$} & \multicolumn{2}{|c|}{$\begin{array}{l}\text { INVPRIV does not } \\
\text { cause GDP }\end{array}$} & \multicolumn{2}{|c|}{$\begin{array}{l}\text { CONST does not } \\
\text { cause GDP }\end{array}$} & \multicolumn{2}{|c|}{$\begin{array}{l}\text { MACHEQ does not } \\
\text { cause GDP }\end{array}$} \\
\hline & $p$ value & significance & $p$ value & significance & $p$ value & significance & $p$ value & significance & $p$ value & significance \\
\hline Argentina & 0.025 & $* *$ & 0.741 & & 0.013 & $* *$ & 0.024 & $* *$ & 0.062 & $*$ \\
\hline $\begin{array}{l}\text { Bolivia (Plurinational } \\
\text { State of) }\end{array}$ & 0.468 & & 0.506 & & 0.391 & & 0.756 & & 0.431 & \\
\hline Brazil & 0.016 & $* *$ & 0.744 & & 0.010 & $* * *$ & 0.078 & $*$ & 0.179 & \\
\hline Chile & 0.979 & & 0.522 & & 0.980 & & 0.583 & & 0.635 & \\
\hline Colombia & 0.346 & & 0.898 & & 0.503 & & 0.880 & & 0.037 & $* *$ \\
\hline Costa Rica & 0.026 & $* *$ & 0.088 & $*$ & 0.648 & & 0.013 & $* *$ & 0.221 & \\
\hline Ecuador & 0.391 & & 0.905 & & 0.407 & & 0.119 & & 0.959 & \\
\hline El Salvador & 0.358 & & 0.715 & & 0.271 & & 0.645 & & 0.161 & \\
\hline Guatemala & 0.704 & & 0.000 & $* * *$ & 0.704 & & 0.912 & & 0.141 & \\
\hline Honduras & 0.595 & & 0.330 & & 0.964 & & 0.232 & & 0.981 & \\
\hline Mexico & 0.140 & & 0.191 & & 0.716 & & 0.251 & & 0.325 & \\
\hline Nicaragua & 0.791 & & 0.033 & $* *$ & 0.176 & & 0.087 & $*$ & 0.239 & \\
\hline Paraguay & 0.795 & & 0.602 & & 0.618 & & 0.481 & & 0.664 & \\
\hline Peru & 0.175 & & 0.355 & & 0.224 & & 0.024 & $* *$ & 0.529 & \\
\hline Dominican Republic & 0.156 & & 0.012 & $* *$ & 0.911 & & 0.108 & & 0.689 & \\
\hline Uruguay & 0.161 & & 0.120 & & 0.300 & & 0.084 & $*$ & 0.364 & \\
\hline $\begin{array}{l}\text { Venezuela (Bolivarian } \\
\text { Republic of) }\end{array}$ & 0.059 & $*$ & 0.152 & & 0.126 & & 0.002 & $* * *$ & 0.176 & \\
\hline
\end{tabular}

Source: prepared by the authors.

Note: GFCF: gross fixed capital formation; INVPUB: public investment; INPRIV: private investment; consT: construction; MACHEQ: machinery and equipment.

Confidence levels for rejection of the null hypothesis: $* * *=1 \%$; ** $=5 \%$; $* 10 \%$.

GDP: gross domestic product.

TABLE 9

Results of the test of null hypothesis 2 on Granger causality of the investment rate by GDP growth

\begin{tabular}{|c|c|c|c|c|c|c|c|c|c|c|}
\hline & \multicolumn{2}{|c|}{$\begin{array}{l}\text { GDP does not } \\
\text { cause GFCF }\end{array}$} & \multicolumn{2}{|c|}{$\begin{array}{l}\text { GDP does not } \\
\text { cause INVPUB }\end{array}$} & \multicolumn{2}{|c|}{$\begin{array}{l}\text { GDP does not } \\
\text { cause INVPRIV }\end{array}$} & \multicolumn{2}{|c|}{$\begin{array}{l}\text { GDP does not } \\
\text { cause CONST }\end{array}$} & \multicolumn{2}{|c|}{$\begin{array}{c}\text { GDP does not } \\
\text { cause MACHEQ }\end{array}$} \\
\hline & $p$ value & significance & $p$ value & significance & $p$ value & significance & $p$ value & significance & $p$ value & significance \\
\hline Argentina & 0.001 & $* * *$ & 0.006 & $* * *$ & 0.001 & $* * *$ & 0.013 & $* *$ & 0.001 & $* * *$ \\
\hline $\begin{array}{l}\text { Bolivia (Plurinational } \\
\text { State of) }\end{array}$ & 0.060 & $*$ & 0.581 & & 0.210 & & 0.164 & & 0.043 & $* *$ \\
\hline Brazil & 0.915 & & 0.689 & & 1.000 & & 0.859 & & 0.781 & \\
\hline Chile & 0.125 & & 0.357 & & 0.098 & $*$ & 0.003 & $* * *$ & 0.470 & \\
\hline Colombia & 0.021 & $* *$ & 0.467 & & 0.088 & $*$ & 0.299 & & 0.007 & $* * *$ \\
\hline Costa Rica & 0.008 & $* * *$ & 0.761 & & 0.165 & & 0.081 & $*$ & 0.018 & $* *$ \\
\hline Ecuador & 0.153 & & 0.695 & & 0.155 & & 0.314 & & 0.119 & \\
\hline El Salvador & 0.008 & $* * *$ & 0.100 & $*$ & 0.017 & $* *$ & 0.088 & $*$ & 0.038 & $* *$ \\
\hline Guatemala & 0.109 & & 0.047 & $* *$ & 0.533 & & 0.004 & $* * *$ & 0.880 & \\
\hline Honduras & 0.058 & $*$ & 0.481 & & 0.022 & $* *$ & 0.575 & & 0.109 & \\
\hline Mexico & 0.393 & & 0.427 & & 0.999 & & 0.925 & & 0.183 & \\
\hline Nicaragua & 0.024 & $* *$ & 0.736 & & 0.130 & & 0.809 & & 0.037 & $* *$ \\
\hline Paraguay & 0.070 & $*$ & 0.952 & & 0.084 & $*$ & 0.051 & $*$ & 0.563 & \\
\hline Peru & 0.050 & $* *$ & 0.343 & & 0.050 & $* *$ & 0.082 & $*$ & 0.175 & \\
\hline Dominican Republic & 0.078 & $*$ & 0.252 & & 0.330 & & 0.044 & $* *$ & 0.347 & \\
\hline Uruguay & 0.000 & $* * *$ & 0.030 & $* *$ & 0.001 & $* * *$ & 0.000 & $* * *$ & 0.002 & $* * *$ \\
\hline $\begin{array}{l}\text { Venezuela (Bolivarian } \\
\text { Republic of) }\end{array}$ & 0.034 & $* *$ & 0.081 & $*$ & 0.194 & & 0.011 & $* *$ & 0.042 & $* *$ \\
\hline
\end{tabular}

Source: prepared by the authors.

Note: GFCF: gross fixed capital formation; INVPUB: public investment; INPRIV: private investment; CONST: construction; MACHEQ: machinery and equipment.

Confidence levels for rejection of the null hypothesis: $* * *=1 \% ; * *=5 \%$; $*=10 \%$.

GDP: gross domestic product. 
rising domestic demand has been based largely on steadily expanding household demand, in response to improving labour market indicators (falling unemployment, rising employment and gains in real wages) and more ready bank lending to families. Another significant element underlying the increase in household consumption was poverty reduction. This is no small matter, since lower-income segments of the population who gain broader access to goods and services show a very high consumption propensity (generally equal or close to 1 ), so the gain in income in these families translates almost entirely into greater consumption. ${ }^{19}$ An important factor in explaining consumption rises in the region is the fact that in 2002-2011 the poverty rate in Latin America fell from $43.9 \%$ to $29.4 \%$. Although the poverty rate is still high and reducing it remains one of the region's major challenges, the change over these 10 years represents a very significant achievement (ECLAC, 2013c). The expansion of the consumption base caused by this set of factors has been key in sustaining the growth of

19 Te link between rising consumption and the investment rate is reflected in a high correlation between the two variables. Jiménez and Manuelito (2013, annex 2) present the results obtained from estimating the correlation coefficients of the rate of variation in total consumption and total investment for the 19 countries included in this study. investment in the commerce sector seen in several Latin American economies.

In a second group of countries, consisting of Argentina, the Bolivarian Republic of Venezuela, Brazil and Nicaragua, it appears more likely that changes in investment drive growth. This could be a sign that, at least in the period under study, growth constraints have tended to come less from insufficient aggregate demand than from limited growth in production capacity as a result of lengthy periods of slack investment in these countries.

Which of the two groups a country corresponds to is of key importance for designing macroeconomic policies for growth and stability. In countries where GDP growth is more likely to precede investment, more importance should be afforded to demand-side policies and countercyclical efforts to keep capacity use high, unless other growth constraints, such as availability of external financing, give rise to a different recommendation. Conversely, where the investment rate precedes changes in GDP growth, policies geared towards stimulating production capacity expansion are more important. In cases lying between the two extreme, the emphasis will vary depending on where the growth constraint lies at any given time, whether in the level of demand or in production capacity.

\section{IV}

\section{Summary and conclusions}

On the basis of estimates not previously available on investment and its components in Latin America, this article reviews the main stylized facts in this connection for the period 1980-2010 and explores causal factors in the nexus between economic growth and gross fixed capital formation (GFCF).

The analysis of the data reveals the low level of investment in Latin America by comparison with other regions and, in particular, with countries that have narrowed the per capita GDP vis-à-vis the developed countries. Three stylized facts emerge in relation to investment in Latin America:

(i) The investment rate remained below $20 \%$ for lengthy periods in 8 of the 19 countries examined.

(ii) Compared with the 1980s, public investment fell as a percentage of GDP in 15 of the 19 countries in the period 1990-1998. Although it began to recover in some of them from 2003 onwards, in 12 of the 19 countries public investment has not regained its 1980s level.

(iii) In the $1990 \mathrm{~s}$, private investment was at its most dynamic for the entire 1980-2010 period and the investment rate rose in 14 of the 19 countries, but its performance was uneven from 2003 on. The private investment rate fell in the subperiod 2003-2010 in 8 countries compared with the figures for 1999-2002, but in 7 it reached its highest levels for the entire 1980-2010 period. This, combined with a slight upturn in public investment in 2003-2010, meant that total investment was at its highest levels in those years.

One of the main factors underlying the increase in investment rates in the subperiod 1990-1998 was the easing of the external constraint, thanks to increased availability 
of foreign exchange owing to economic opening and the rising purchasing power of exports on the back of higher prices and plummeting international prices for capital goods. Nevertheless, national saving continued to be insufficient to cover investment, so external saving remained an important source of financing. However, in contrast to the 1980s, the components of external saving changed significantly from the 1990s onward, with FDI playing an increasingly important role. ${ }^{20}$

The investment rate rose again in the subperiod 2003-2010. Contributing to this, as in 1990-1998, was the diminishing influence of the external constraint a limitation on financing. Some countries in the region even experienced negative external saving for several years running, owing to the combined effect of rising disposable national income on the back of terms-of-trade gains and changes in the macroeconomic policy framework, which led to a hefty increase in national saving. The counterpart of this was a decline in external borrowing and build-up of international reserves and savings in

${ }^{20}$ In this regard, see ECLAC (2013a, chapter I). sovereign funds. The patterns of national saving in the 2003-2010 represented the main difference with respect to the subperiod 1990-1998. The investment ratio rose in both subperiods, but higher national saving during the second, together with a persistently larger share of less volatile financial flows in external saving — which had begun in the 1980 s - reduced external vulnerability and opened up space for countercyclical policy action when the recent global financial crisis hit.

With respect to the empirical analysis of the link between growth and investment, the results obtained show that, in general, changes in the rate of GDP variation precede changes in the investment rate. Similar results are obtained from analysis of the link between GDP growth rate and the rates of private investment and investment in machinery and equipment. In only a few cases - although important ones because of their relative size in the region- it was found that change in investment Granger-caused (1969) growth. These results are significant because they help to identify the factors acting as growth constraints in each case, and thus to design macroeconomic policy to stimulate growth accordingly.

\section{Bibliography}

Blomström, Magnus, Robert Lipsey and Mario Zehjan (1993), "Is fixed investment the key to economic growth?", NBER Working Paper, No. 4436, Cambridge, Massachusetts, National Bureau of Economic Research (NBER).

Bukhari, Adnan, Liaqat Ali and Mahpara Saddaqat (2007), "Public investment and economic growth in the three little dragons", International Journal of Business and Information, vol. 2, No. 1.

Cheung, Yin-Wong, Michael Dooley and Vladyslav Sushko (2012), "Investment and growth in rich and poor countries", NBER Working Paper, No. 17788, Cambridge, Massachusetts, National Bureau of Economic Research (NBER).

Cullison, W.E. (1993), "Public investment and economic growth", Federal Reserve Bank of Richmond Economic Quarterly, vol. 79, No. 4, Richmond, Federal Reserve Bank of Richmond.

ECLAC (Economic Commission for Latin America and the Caribbean) (2014), Economic Survey of Latin America and the Caribbean, 2014 (LC/G.2619-P), Santiago, Chile. United Nations publication, Sales No. E.14.II.G.3.

(2013a), Economic Survey of Latin America and the Caribbean, 2013 (LC/G.2574-P), Santiago, Chile. United Nations publication, Sales No. E.13.II.G.3.

(2013b), Foreign Direct Investment in Latin America and the Caribbean 2012 (LC/G.2571-P), Santiago, Chile. United Nations publication, Sales No. E.13.II.G.4.

(2013c), Social Panorama of Latin America, 2012 (LC/G.2557-P), Santiago, Chile. United Nations publication, Sales No. E.13.II.G.6.

(2012), Statistical Yearbook for Latin America and the Caribbean, 2012 (LC/G.2554-P), Santiago, Chile. United Nations publication, Sales No. E/S.13.II.G.1.
(2011), Economic Survey of Latin America and the Caribbean 2010-2011 (LC/G.2506-P), Santiago, Chile. United Nations publication, Sales No. E.11.II.G.3.

(2009), "América Latina y el Caribe: Series históricas de estadísticas económicas 1950-2008", Cuadernos Estadísticos de la CEPAL, No. 37 (LC/G.2415-P), Santiago, Chile. United Nations publication, Sales No. S.09.II.G.72.

Granger, C.W.J. (1969), "Investigating causal relations by econometric models and cross-spectral methods", Econometrica, vol. 37, No. 3, Econometric Society.

Jiménez, Luis Felipe and Sandra Manuelito (2013), "Rasgos estilizados de la relación entre inversión y crecimiento en América Latina y el Caribe: 1980-2012", Macroeconomía del Desarrollo series, No. 136 (LC/L.3704), Santiago, Chile, Economic Commission for Latin America and the Caribbean (ECLAC).

Manuelito, Sandra and Luis Felipe Jiménez (2013), "La inversión y el ahorro en América Latina: nuevos rasgos estilizados, requerimientos para el crecimiento y elementos para una estrategia para fortalecer su financiamiento", Macroeconomía del Desarrollo series, No. 129 (LC/L.3603), Santiago, Chile, Economic Commission for Latin America and the Caribbean (ECLAC).

Peltonen, Thomas, Ricardo Sousa and Isabel Vansteenkiste (2012), "Investment in emerging market economies", Empirical Economics, vol. 43, No. 1, Springer.

Sala-i-Martin, Xavier (1997), "I just ran two millions regressions", American Economic Review, vol. 87, No. 2, Nashville, Tennessee, American Economic Association.

Toulaboe, Dosse, Rory Terry and Thomas Johansen (2009), "Foreign direct investment and economic growth in developing countries", Southwestern Economic Review, vol. 36, No. 1, Southwestern Economic Society. 